\title{
Pulmonicola cochleotrema (Digenea: Opisthotrematidae) in Antillean manatees (Trichechus manatus manatus) from the North-eastern region of Brazil
}

\author{
JOÃO CARLOS GOMES BORGES ${ }^{1,2}$, LARISSA MOLINARI JUNG ${ }^{2}$, VITOR LUZ CARVALHO ${ }^{3}$, ANDRÉ LUCAS DE \\ OLIVEIRA MOREIRA ${ }^{2}$, FERNANDA LÖFFLER NIEMEYER ATTADEMO ${ }^{4}$, RAFAEL ANTONIO \\ NASCIMENTO RAMOS ${ }^{1}$ AND LEUCIO CÂMARA ALVES ${ }^{1}$ \\ ${ }^{1}$ Programa de Pós-Graduação em Ciência Animal Tropical, Departamento de Medicina Veterinária, Universidade Federal Rural de \\ Pernambuco, Rua Dom Manoel de Medeiros, s/n, Dois Irmãos, CEP: 52.171-90o, Recife, Pernambuco, Brasil, ${ }^{2}$ Fundação Mamíferos \\ Aquáticos - FMA, Avenida 17 de Agosto, ${ }^{\circ}{ }^{2001}$, Casa Forte, CEP: 52.061-540, Recife, Pernambuco, Brasil, ${ }^{3}$ Associação de Pesquisa \\ e Preservação de Ecossistemas Aquáticos - AQUASIS, SESC Iparana, rua José de Alencar, 150, CEP: 61.627-210, Caucaia, CE, Brasil, \\ ${ }^{4}$ Centro Nacional de Pesquisa e Conservação de Mamíferos Aquáticos/Instituto Chico Mendes de Conservação da Biodiversidade, \\ Estrada do Forte Orange, s/n, caixa postal nº
}

\begin{abstract}
Currently, little is known about the helminth fauna in sirenian species. Therefore, the objective of this study was to assess the frequency of infection by Pulmonicola cochleotrema in Antillean manatees (Trichechus manatus manatus), in the North-eastern region of Brazil. Between the years of 1989 and 2014, 88 manatees found on the North-eastern Brazilian coast were clinically examined. They included animals that were found dead, animals maintained in captivity and specimens reintroduced into conservation areas. During their physical examination, helminths present in necropsied carcasses and in reintroduced animals were collected, as well as faecal samples. Parasites were detected in $7.95 \%$ (7/88) of the animals; all specimens collected being identified as P. cochleotrema. Only adult manatees were infected, and in two cases clinical signs were observed. This is the first report on the occurrence of $\mathrm{P}$. cochleotrema in Antillean manatees in the states of Paraíba and Sergipe, in the North-eastern coast of Brazil.
\end{abstract}

Keywords: Conservation, aquatic mammals, sirenians, helminth, trematode, parasite, parasitology, wildlife medicine, infection, clinical signs

Submitted 19 October 2015; accepted 9 June 2016

\section{INTRDDUCTION}

Manatees are aquatic mammals that are considered vulnerable to extinction according to IUCN (2014), and endangered based on the Brazilian Red List (Mma, 2014). In Brazil, the presence of these animals has been reported on the coast and in estuary areas of all states from Amapá to Sergipe, with some discontinuous areas along the coast (Luna et al., 2008; Lima et al., 2011; Alves et al., 2013).

For a long time, the indiscriminate hunting of animals was considered the major threat to manatee conservation in Brazil (Domning, 1982; Lima et al., 2011). Moreover, other factors such as accidental death in fishing nets (Meirelles, 2008), the silting of estuaries, environmental degradation (Nishida et al., 2008; Icmbio, 2011), indiscriminate use of motorized boats (Borges et al., 2007), contamination of water resources (Anzolin et al., 2012) and the stranding of manatee calves (Parente et al., 2004; Meirelles, 2008) contributed to the reduction of the manatee population.

Corresponding author:

J.C. Borges

Email: jcgborges@hotmail.com
It is well known that the presence of certain pathogens such as bacteria (Vergara-Parente et al., 2003), viruses (Ghim et al., 2014) and parasites (Borges et al., 2011; Bando et al., 2014) may interfere in the health of these animals and in many cases have been associated with their mortality (Buergelt et al., 1984; Beck \& Forrester, 1988). So far, about 25 species of helminth parasites have been reported as infecting manatees (Mignucci-Giannoni et al., 1999a; Lieven et al., 2011; Bando et al., 2014), however, clinical signs are associated with the parasitic infection in only a few of these cases (Beck \& Forrester, 1988; Bossart, 2001).

From 1991 to 2003, a large copromicroscopic survey using different techniques (i.e. direct methods, flotation and sedimentation) was conducted in Brazil, which showed that all manatees studied were negative for the presence of helminths (Borges et al., 2004). On the other hand, a research study carried out in the state of Ceará in 2009, detected Pulmonicola cochleotrema in the upper respiratory tract of free-living specimens (Carvalho et al., 2009).

Therefore, in order to bridge the gap on the knowledge of helminths fauna in sirenian species, this study was to assess the frequency of infection by Pulmonicola cochleotrema in Antillean manatees (Trichechus manatus manatus), in the North-eastern region of Brazil. 


\section{MATERIALS AND METHDDS}

Between the years of 1989 and 2014, 88 manatees were studied, 39 specimens representing stranded animals found dead, rescued between the states of Sergipe $\left(11^{\circ} 25^{\prime} 32 \mathrm{~S}\right.$ $\left.37^{\circ} 19^{\prime} 18 \mathrm{~W}\right)$ and Rio Grande do Norte (04 $49^{\prime} 55 \mathrm{~S}$ $37^{\circ} 15^{\prime} 09 \mathrm{~W}$ ). The carcasses were necropsied (Vergara-Parente, 2005) and careful examinations of the respiratory and digestive systems were performed (Marigo \& Andrade, 2005).

In addition, considering the actions planned for the strategy of manatee conservation in Brazil (ICMBIO, 2011), 49 live specimens were monitored; some of them during their rehabilitation process and maintenance in pools $(\mathrm{N}=23)$, some during the rehabilitation period in captivity, built in the natural environment $(\mathrm{N}=5)$, and others after reintroduction $(\mathrm{N}=21)$

All animals in captivity and those reintroduced were physically examined and faecal samples were collected for laboratory analyses. The age of animals was estimated based on data previously published on Florida and Antillean manatees (Marmontel, 1993; Borges et al., 2012). In the physical examination, three reintroduced animals eliminated parasites from their nostrils during breathing.

All faecal samples and helminths collected were fixed and preserved in a solution containing alcohol, formalin, glacial acetic acid and distilled water. Afterwards, the faecal material was analysed through sedimentation and flotation techniques (Bando et al., 2014) and helminths were clarified in lactophenol, stained and mounted on microscope slides for morphological identification (Amato, 1985). Parasites were measured and identified using previous descriptions (Blair, 1981, 2005; Carvalho et al., 2009).

In order to investigate the interaction between infection by $P$. cochleotrema and gender (male or female) and/or age (calf, young or adult) the log-linear method was used (Quinn \& Keough, 2002). All analyses were performed by the $\operatorname{glm}()$ function of the MASS package (Venables \& Ripley, 2002) of Software R (R Core Team, 2014).

All procedures herein performed were approved by the Sistema de Autorização e Informação em Biodiversidade (SISBIO) (licence number: 33.819-1) and by the Ethics Committee of Animal Experimentation (ECAE) of the Universidade Federal Rural de Pernambuco (licence number: 23082.011095/2013).

\section{RESULTS}

Out of 88 animals analysed, $7.95 \%$ (7/88) scored positive for the presence of $P$. cochleotrema in the nostrils (Fig. 1), trachea and/or bronchi. The trematodes herein found presented oval bodies with $6.6 \mathrm{~mm}$ in length and $4.83 \mathrm{~mm}$ in width. Morphologically they were concave ventrally and convex dorsally. In addition, they presented an oral sucker subterminal with transversal opening, branched intestinal caecum and multilobated and irregular ovaries. Testicles were rounded, multilobulated, and located in the posterior third of the body. All trematodes were identified as P. cochleotrema (Digenea: Opisthotrematidae).

Although a higher frequency of infection was observed in females $(71.42 \% ; 5 / 7)$, this gender did not present any correlation with the occurrence of the parasite $(\mathrm{gl}=1 ; F=0 ; P=1)$. Conversely, age was correlated with the occurrence of infection

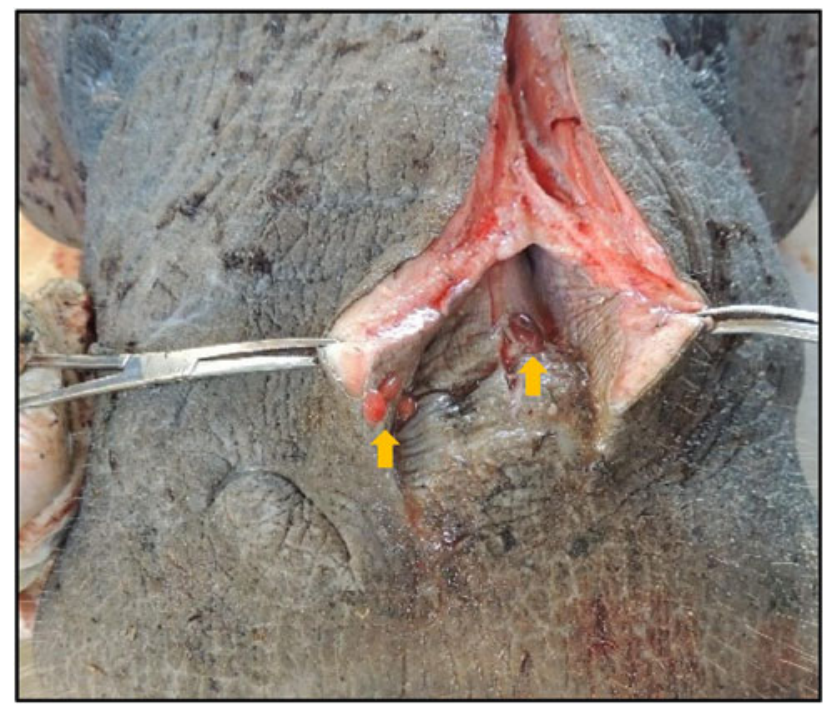

Fig. 1. Pulmonicola cochleotrema (Digenea: Opisthotrematidae) found in the nostril of Antillean manatee.

by $P$. cochleotrema $(\mathrm{gl}=2 ; F=4.6193 ; P<0.001)$, because all positive animals were adults. On the other hand, no correlation between the positivity and gender/age was observed.

The frequencies of infection in dead and live animals were $10.25 \%(4 / 39)$ and $6.12 \%(3 / 49)$, respectively. Positive results were obtained only in free-living animals, including native and reintroduced species. No parasites were detected in animals maintained in captivity.

In three reintroduced specimens $(6.12 \% ; 3 / 49)$, respiratory changes (i.e. atypical noises and nasal mucous secretion) were observed. In addition, clinical signs suggestive of bronchitis and bronchopneumonia were reported. Some specimens eliminated parasites from the nostrils during breathing. All clinical signs herein reported are compatible with infection by $P$. cochleotrema.

All analyses of faeces scored negative for the presence of eggs, larvae and/or oocysts.

\section{DISCUSSIDN}

The frequency of infection by $P$. cochleotrema observed in the present research study (i.e. 7.95\%) was lower than that reported in a previous study in the USA, where a positivity of $38 \%$ was detected (Beck \& Forrester, 1988), and in Puerto Rico (Mignucci-Giannoni et al., 1999b) where $26 \%$ of manatees were parasitized by this trematode. Similarly, a study conducted in the state of Ceará, Brazil, reported a positivity of $26.7 \%$ (Carvalho et al., 2009).

The findings of this study are relevant and expand the knowledge on the occurrence area (states of Paraíba and Sergipe) of $P$. cochleotrema in Antillean manatees in Brazil.

Special attention has been given to the factors that contributed to the occurrence of $P$. cochleotrema in manatees in the last years. Until 2013, no infection had been reported in Antillean manatees (free-living animals or in captivity) in the states of Sergipe, Alagoas, Pernambuco, Paraíba and Rio Grande do Norte. In addition, during a large copromicroscopic survey conducted from 1991 to 2003, and during the examination of manatee carcasses (Borges et al., 2004), no trematode species were detected. 
In order to better understand the epidemiological factors associated with the infection by $P$. cochleotrema in sirenian species, as well as the host-parasite relationship, it is pivotal to know the biology of this trematode. Indeed, until now, information about its life cycle in manatees, as well as factors influencing its survival in environmental conditions and routes of infection remain unknown (Carvalho et al., 2009).

In fact, it is believed that $P$. cochleotrema can use molluscs or crustaceans as intermediate hosts (Beck \& Forrester, 1988). These invertebrates are found attached to algae and seagrasses, which are important sources of food for manatees (Borges et al., 2008). Therefore, it is likely that the infection occurs after ingestion of these (Blair, 1981; Beck \& Forrester, 1988; Bando et al., 2014). In addition, it has been proved in other studies that environmental factors such as salinity and water temperature can influence the occurrence of $P$. cochleotrema (Beck \& Forrester, 1988; Carvalho et al., 2009).

The infection by $P$. cochleotrema was observed only in native and reintroduced species. Therefore, it is likely that intrinsic factors related to the condition of free-living animals may play an important role in the susceptibility to infection of the Antillean manatees herein studied. Moreover, it has been demonstrated that manatees living in the Florida Peninsula were more exposed to the infection due to their displacements and consequent diversity of food resources ingested by them (Bando et al., 2014). In Brazil, this sirenian species may also move over a large area, which makes them vulnerable to infection by these parasites (Lima et al., 2012; Normande et al., 2014).

Most likely, the lack of infections by this trematode in animals maintained in captivity, especially in pools with physical and chemical water treatment, occurs due to the absence of intermediate hosts.

Only adult animals were found infected with P. cochleotrema. This finding is similar to another study previously reported, in which only older animals were affected, probably because these animals use a large area of habitat during their life-time (Beck \& Forrester, 1988).

The presence of atypical noises and nasal mucous secretion in animals naturally infected by $P$. cochleotrema has already been reported (Beck \& Forrester, 1988; Mignucci-Giannoni et al., 1999b). In fact, clinical signs related to the infection by this trematode are seldom recorded (Bossart, 2001), but when they occur the animal may present chronic rhinitis, pulmonary oedema, pneumonia, and in some cases these may lead to death (Beck \& Forrester, 1988).

The absence of helminth eggs and larvae in the faeces herein analysed is similar to the findings previously reported by Borges et al. (2004). Therefore, it is important to adopt new tools with higher sensitivity in order to improve diagnoses of parasite infections.

In conclusion, the displacement ability of Antillean manatees along the Brazilian coast might be an important factor for the spreading of $P$. cochleotrema. In addition, it is important to note that this is the first report of manatee infection by this trematode in the states of Paraiba and Sergipe from the North-eastern region of Brazil.

\section{ACKNOWLEDGEMENTS}

The authors kindly thank all the staff of the Fundação Mamíferos Aquáticos and of the Centro Mamíferos
Aquáticos/ICMBio, as well as of Projeto Viva o Peixe-Boi Marinho, who were important during the rescue, rehabilitation and reintroduction activities of the manatees used in this study. This paper employed data generated by the Regional Program for Stranding and Abnormal Activity Monitoring in the Sergipe-Alagoas Basin carried out by the Fundação Mamíferos Aquáticos, Instituto de Tecnologia e Pesquisa and Petrobras, as a mitigating measure of the Federal Environmental Licensing conducted by the Brazilian environmental Agency IBAMA.

\section{FINANCIAL SUPPDRT}

The authors would like to thank CAPES for their financial support.

\section{REFERENCES}

Alves M.D.O., Schwamborn R., Borges J.C.G., Marmontel M., Costa A.F.C., Schettini C.A.F. and Araújo M.E. (2013) Aerial survey of manatees, dolphins and sea turtles off northeastern Brazil. Biological Conservation 161, 91-100.

Amato J.F. (1985) Manual de técnicas para a preparação de coleções zoológicas. 8. Platelmintos (temnocefálidos, trematódeos, cestóides, cestodários) e acantocéfalos. São Paulo: Sociedade Brasileira de Zoológicos.

Anzolin D.G., Sarguis J.E.S., Diaz E., Soares D.G., Serrano I.L., Borges J.C.G., Souto A.S., Taniguchi S., Montone R.C., Bainy A.C.D. and Carvalho P.S.M. (2012) Contaminant concentration, biochemical and hematological biomarkers in blood of West Indian manatees Trichechus manatus from Brazil. Marine Pollution Bulletin 64, $1402-1408$.

Bando M., Larkin I.V., Wright S.D. and Greiner E.C. (2014) Diagnostic stages of the parasites of the Florida manatee, Trichechus manatus latirostris. Journal of Parasitology 100, 133-138.

Beck C., Forrester D.J. (1988) Helminths of the Florida manatee, Trichechus manatus latirostris, with a discussion and summary of the parasites of Sirenians. Journal of Parasitology 74, 628-637.

Blair D. (1981) The Monostome flukes (Digenea: Families Opisthotrematidae Poche and Rhabdiopoeidae Poche) parasitic in Sirenians (Mammalia: Sirenia). Australian Journal of Zoology Supplementary Series 81, 1-54.

Blair D. (2005) Family Opisthotrematidae Poche, 1926. In Jones A., Bray R.A. and Gibson D.I. (eds) Keys to Trematoda. Wallingford: CABI; London: The Natural History Museum, pp. 401-406.

Borges J.C.G., Alves L.C., Faustino M.A.G. and Marmontel M. (2011) Occurrence of Cryptosporidium spp. in Antillean manatees (Trichechus manatus) and Amazonian manatees (Trichechus inunguis) from Brazil. Journal of Zoo and Wildlife Medicine 42, 593-596.

Borges J.C.G., Araújo P.G., Anzolin D.G. and Miranda G.E.C. (2008) Identificação de itens alimentares constituintes da dieta dos peixesbois marinhos (Trichechus manatus) na região Nordeste do Brasil. Biotemas 21, $77-81$.

Borges J.C.G., Freire A.C.B., Attademo F.L.N., Serrano I.L., Anzolin D.G., Carvalho P.S.M. and Vergara-Parente J.E. (2012) Growth pattern differences of captive born Antillean manatee (Trichechus manatus) calves and those rescued in the Brazilian Northeastern Coast. Journal of Zoo and Wildlife Medicine 43, 494-500.

Borges J.C.G., Vergara-Parente J.E., Alvite C.M.C., Marcondes M.C.C. and Lima R.P. (2007) Embarcações motorizadas: uma ameaça aos 
peixes-bois marinhos (Trichechus manatus) no Brasil. Biota Neotropica 7, 199-204.

Borges J.C.G., Vergara-Parente J.E., Lima R.P., Brito F.L.C. and Alve L.C. (2004) Helmintose gastrointestinal em peixe-boi marinho (Trichechus manatus), no Brasil. In $11^{a}$ Reunión de Especialistas em Mamíferos Acuáticos de América del Sur, Quito. Solamac (ed.), Pontificia Universidad Católica del Ecuador, pp. 63-64.

Bossart G.D. (2001) Manatees. In Dierauf L.A. and Gulland F.M.D. (eds) CRC handbook of marine mammal medicine. Boca Raton, FL: CRC Press, pp. 939-958.

Buergelt C.D., Bonde R.K., Beck C.A. and O’Shea T.J. (1984) Pathologic findings in manatees in Florida. Journal of the American Veterinary Medical Association 185, 1331-1334.

Carvalho V.L., Meirelles A.C.O., Motta M.R.A., Maia D.C.B.S.C., Campello M.V.M. and Bevilaqua C.M.L. (2009) Occurrence of Pulmonicola cochleotrema (Syn. Cochleotrema cochleotrema) (Digenea: Opisthotrematidae) in Antillean manatees (Trichechus manatus manatus) in Brazil. Latin American Journal of Aquatic Mammals 7, 47-52.

Domning D.P. (1982) Commercial exploitation of manatees Trichechus in Brazil c. 1785-1973. Biological Conservation 22, 101-126.

Ghim S., Joh J., Mignucci-Giannoni A.A., Rivera-Guzmán A.L., Falcón-Matos L., Alsina-Guerrero M.M., Rodríguez-Villanueva M., Jenson A.B. and Bossart G.D. (2014) Genital papillomatosis associated with two novel mucosotropic papillomaviruses from a Florida manatee (Trichechus manatus latirostris). Aquatic Mammals 40 189-194.

ICMBIO (2011) Plano de Ação Nacional para a Conservação dos Sirênios: peixe-boi-da-Amazônia: Trichechus inunguis e peixe-boi marinho: Trichechus manatus. Brasília: Instituto Chico Mendes de Conservação da Biodiversidade.

IUCN (2014) Red list of threatened species. http://www.iucnredlist.org.

Lieven A.F.V., Uni S., Ueda K., Barbuto M. and Bain O. (2011) Cutidiplogaster manati n. gen., n. sp. (Nematoda: Diplogastridae) from skin lesions of a West Indian manatee (Sirenia) from the Okinawa Churaumi Aquarium. Nematology 13, 51-59.

Lima R.P., Alvite C.M.C., Reid J.P. and Júnior A.B. (2012) Distribuição espacial e temporal de peixes-bois (Trichechus manatus) reintroduzidos no litoral nordeste do Brasil. Natural Resources 2, 63-8o.

Lima R.P., Paludo D., Soavinski R.J., Silva K.G. and Oliveira E.M. (2011) Levantamento da distribuição, ocorrência e status de conservação do Peixe-Boi Marinho (Trichechus manatus, Linnaeus, 1758) no litoral nordeste do Brasil. Natural Resources 1, 41-57.

Luna F.O., Lima R.P., Araújo J.P. and Passavante J.Z.O. (2008) Status de conservação do peixe-boi marinho (Trichechus manatus manatus, Linnaeus, 1758) no Brasil. Revista Brasileira de Zoociências 10, $145-153$.

Marigo J. and Andrade A.L.V. (2005) Parasitologia. In Vergara-Parente J.E. (ed.) Protocolo de conduta para encalhes de mamíferos aquáticos. Pernambuco: Ibama Press, pp. 280-290.
Marmontel M. (1993) Age determination and population biology of the Florida manatee, Trichechus manatus latirostris. Dissertation. University of Florida, Florida.

Meirelles A.C.O. (2008) Mortality of the Antillean manatee, Trichechus manatus manatus, in Ceará State, North-eastern Brazil. Journal of the Marine Biological Association of the United Kingdom 88, $1133-1137$

Mignucci-Giannoni A.A., Beck C.A., Montoya-Ospina R.A. and Williams E.H. (1999a) Parasites and commensals of the West Indian Manatee from Puerto Rico. Journal of Helminthology 66, $67-69$.

Mignucci-Giannoni A.A., Williams E.H., Toyos-Gonzáles G.M., Pérez-Padilla J., Rodríguez-Lópes M.A., Veja-Guerra M.B. and Ventura-González M. (1999b) Helminths from a stranded manatee in the Dominican Republic. Veterinary Parasitology 81, 69-71.

Mma. (2014) Portaria $\mathrm{N}^{\circ} 444$, de 17 de dezembro de 2014. Diário Oficial da União 245, 121-122.

Nishida A.K., Nordi N. and Alves R.R.N. (2008) Aspectos socioeconômicos dos catadores de moluscos do litoral paraibano, Nordeste do Brasil. Revista de Biologia e Ciência da Terra 8, 207-215.

Normande I.C., Luna F.O., Malhado A.C.M., Borges J.C.G., Junior P.C.V., Attademo F.L.N. and Ladle R.J. (2014) Eighteen years of Antillean manatee Trichechus manatus manatus releases in Brazil: lessons learnt. Oryx 49, $1-7$.

Parente C.L., Vergara-Parente J.E. and Lima R.P. (2004) Strandings of Antillean manatees, Trichechus manatus manatus, in Northeastern Brazil. Latin American Journal Aquatic Mammals 3, 69-75.

Quinn G.P. and Keough M.J. (2002) Experimental design and data analysis for biologists. New York, NY: Cambridge University Press.

R Core Team (2014) R: A language and environment for statistical computing. http://www.r-project.org/.

Venables W.N. and Ripley B.D. (2002) Modern applied statistics with S, 4th edition. New York, NY: Springer.

Vergara-Parente J.E. (2005) Necropsia de Sirênios. In Vergara-Parente J.E. (ed.) Protocolo de conduta para encalhes de mamíferos aquáticos. Recife, Brasil: Ibama, pp. 185-203.

and

Vergara-Parente J.E., Sidrim J.J.C., Teixeira M.F.S., Marcondes M.C.C. and Rocha M.F.G. (2003) Salmonellosis in an Antillean manatee (Trichechus manatus manatus) calf: a fatal case. Aquatic Mammals 29, $131-136$.

\section{Correspondence should be addressed to:}

J.C.G. Borges

Programa de Pós-Graduação em Ciência Animal Tropical, Departamento de Medicina Veterinária, Universidade Federal Rural de Pernambuco, Rua Dom Manoel de Medeiros, s/n, Dois Irmãos, CEP: 52.171-900, Recife, Pernambuco, Brasil

email: jcgborges@hotmail.com 